\title{
PERANCANGAN ALAT TENUN TRADISIONAL NTT DENGAN METODE THREE IN ONE DI RUMAH TENUN KAMPUNG ALOR
}

\author{
Rima Nindia Selan ${ }^{1, a}$, Ariency K. Ada Kale $2, b$, Theodora M. \\ Tualaka ${ }^{3, c}$ \\ 1,2,3 Program Studi Teknik Pembuatan Tenun Ikat, Fakultas Sains dan Teknik, \\ Universitas Nusa Cendana, Kupang, NTT \\ rima_selan@staf.undana.ac.id
}

\begin{abstract}
Abstrak
NTT adalah salah satu dari beberapa daerah penghasil tenun di Indonesia, kain tenun ikat dari NTT menjadi kebanggaan masyarakat provinsi NTT, karena secara adat dan budaya memiliki banyak fungsi, misalnya sebagai busana yang dipakai dalam pesta, tari - tarian, upacara adat, penghargaan kepada tamu yang berkunjung, sebagai mas kawin, sebagai pemberian dalam acara kematian dan sebagai wujud penghargaan, dan masih banyak lagi. Bahkan menurut para ahli NTT adalah salah satu dari beberapa daerah penghasil tenun di Nusantara tercatat paling awal dalam mengembangkan corak ragam hias tenun ( Nadek, 2018). Proses pembuatan kain tenun ini dilakukan secara manual. Mulai dari proses ikat untuk pembentukan motif, sampai pencelupan warna yang dilakukan berulang-ulang. Ini karena satu warna saja butuh waktu selama 2-3 hari untuk pengeringan. Kemudian, benang-benang yang sudah diikat ini akan ditenun untuk menjadi sebuah kain sarung. Nah, bayangkan, itu baru proses awalnya. Untuk menjadi kain sempurna, tiap penenun butuh waktu sedikitnya 3 bulan. Postur kerja yang salah sering diakibatkan oleh letak fasilitas yang kurang sesuai dengan antropometri pengrajin sehingga mempengaruhi kinerja pengrajin. Postur kerja yang tidak alami misalnya postur kerja selalu berdiri, jongkok, membungkuk, mengangkat, dan mengangkut dalam waktu yang lama dapat menyebabkan ketidaknyamanan dan nyeri pada salah satu anggota tubuh. Kelelahan dini pada pekerja juga dapat menimbulkan penyakit akibat kerja dan kecelakaan kerja yang mengakibatkan cacat bahkan kematian (Mufti, dkk. 2013). Berdasarkan hasil pengamatan langsung pada pengerjaan Tenun Ikat di Sentra Tenun Kampung Alor, kondisi kerja yang tidak ergonomis ditunjukan oleh adanya posisi duduk yang berlangsung lama pada proses menenun, sehingga mengakibatkan timbulnya keluhan-keluhan pada tubuh pengrajin diantaranya pada punggung, pinggang, bokong, pantat, dan leher yang jangka panjang akan menimbulkan kelelahan kronis dan rasa sakit pada anggota - anggota tubuh tadi. Penelitian ini bertujuan merancang alat tenun yang dikombinasikan fungsinya menjadi three in one, hal ini dimaksudkan untuk mempersingkat waktu pengerjaan tenun ikat yang berpengaruh juga untuk minimalisasi keluhan - keluhan pada tubuh pengrajin. Dalam penelitian ini, metode yang digunakan adalah metode perancangan berdasarkan pengamatan dan observasi. Tujuan dari metode tersebut adalah untuk mengurangi atau menghilangkan gerakan yang kurang efektif agar mendapatkan gerakan yang cepat dan efektif serta mempersingkat waktu kerja.
\end{abstract}

Kata kunci : alat tenun tradisional, perancangan, Sentra Tenun Kampung Alor

Abstract
NTT is one of several weaving-producing regions in Indonesia, ikat cloth from NTT has
become the pride of the people of NTT province, because traditionally and culturally it
has many functions, for example as clothing worn in parties, dances, traditional
ceremonies, awards to guests. who visit, as a dowry, as a gift at the event of death and
as a form of appreciation, and much more. Even according to experts, NTT is one of the


few weaving-producing regions in the archipelago that was recorded as the earliest in developing decorative weaving patterns (Nadek, 2018). The process of making this woven fabric is done manually. Starting from the process of tying for the formation of motifs, until the color dyeing is done repeatedly. This is because just one color takes 2-3 days to dry. Then, these tied threads will be woven into a sarong. Well, imagine, that's just the beginning of the process. To become a perfect fabric, each weaver takes at least 3 months. Wrong work postures are often caused by the location of the facilities that are not in accordance with the anthropometry of the craftsmen so that it affects the performance of the craftsmen. Unnatural work postures such as working postures of always standing, squatting, bending, lifting, and transporting for a long time can cause discomfort and pain in one member of the body. Early fatigue in workers can also cause work-related diseases and work accidents that result in disability and even death (Mufti et al. 2013). Based on direct observations on the weaving of Ikat at the Kampung Alor Weaving Center, non-ergonomic working conditions are indicated by the existence of a long sitting position in the weaving process, resulting in complaints of the craftsman's body including on the back, waist, buttocks, buttocks, and long-term neck will cause chronic fatigue and pain in the limbs earlier. This study aims to design a loom that combines its functions into three in one, this is intended to shorten the time of ikat weaving which also affects the minimization of complaints on the body of the craftsmen. In this study, the method used is a design method based on observations and observations. The purpose of this method is to reduce or eliminate less effective movements in order to get fast and effective movements and shorten working time.

Keywords: traditional loom, design, Kampung Alor Weaving Center

\section{PENDAHULUAN}

Wisatawan dari berbagai penjuru dunia mengunjungi Indonesia dengan berbagai alasan. Bagaimana tidak, Indonesia menawarkan beragam destinasi pariwisata yang memang telah mendunia dan diakui keindahannya sehingga sungguh sangat sayang untuk dilewatkan. Mulai dari wilayah pegunungan sampai pantai menawarkan berbagai objek wisata yang telah dikemas sedemikian rupa dengan keindahan tiada tara.

Namun yang tidak kalah penting yang sangat menarik perhatian wisatawan adalah budaya Indonesia. Indonesia terdiri dari beragam suku bangsa dengan ciri khas masing-masing. Dari Sabang sampai Merauke, kehidupan setiap masyarakatnya tidak luput dari adat istiadat yang sangat kental dan kadang mendominasi suatu wilayah. Ciri khas dari sebuah wilayah di Indonesia tidak bisa juga dipisahkan dari kehidupan masyarakatnya, entah dari kebiasaan atau hal-hal yang diwariskan secara turunmenurun.

Meskipun anggapan masyarakat terhadap budaya tidak terlepas dari barang atau benda kerajinan baik itu seni pahat atau lukis, maupun seni gerak dan suara, namun arti budaya jauh melampaui itu semua. Budaya sendiri menurut Soemarjan dan Soemardi (1985) adalah segala hasil karya, rasa, dan ciptaan masyarakat. Sedangkan Koentjaraningrat mendefinisikan kebudayaan dengan lebih luas lagi, yaitu merupakan system gagasan, tindakan dan hasi karya yang dihasilkan dalam rangka kehidupan manusia dan dijadikan hak milik manusia melalui proses belajar.

Hasil dari kebudayaan yang biasa dipahami di kalangan masyarakat adalah produk budaya, entah itu dalam bentuk pahatan, lukisan maupun benda-benda yang sifatnya bisa disentuh atau diraba lainnya. Salah satu alasan para wisatawan mengunjungi negara kita adalah karena produk yang menjadi ciri 
khas, entah itu karena keunikan produk, fungsi, maupun bahan dasar yang digunakan untuk membentuknya.

Di Nusa Tenggara Timur (NTT) sendiri, salah satu budaya yang dipertahankan hingga saat ini adalah budaya menenun yang dapat menghasilkan kain tenun.Pada zaman dahulu kain tenun terbuat dari bahanbahan seperti dedaunan, kulit kayu dan binatang. Proses dan teknik pembuatan pun masih sangat sederhana karena dibuat secara manual. Seiring dengan perkembangan zaman dan teknologi, memang terdapat perubahan pada pembuatan kain tenun terutama pada proses pembuatan dan ragam hias serta corak kain tenun. Namun lain halnya dengan bahan pembuatan kain tenun, masih banyak tempat atau wilayah penghasil kain tenun di NTT yang masih mempertahankan penggunaan bahan alami dan alat yang masih sangat sederhana yang tersedia disekitar mereka untuk membuat kain tenun. Penggunaan bahan alami dan alat tenun ini bertujuan untuk mempertahankan keaslian dan melestarikan kain tenun sebagai salah satu warisan budaya mereka.

Namun dalam penggunaan alat tenun yang sederhana ini terdapat beberapa masalah diantaranya masalah pada kesehatan pengrajin dan masalah waktu serta tempat yang tidak efisien dalam proses pengerjaan. Oleh karena itu, perlu adanya inovasi baru yang dapat mengatasi masalah tersebut sehingga efisiensi dalam proses pengerjaan dapat terwujud.

Berdasarkan kajian diatas, penulis tertarik untuk melakukan penelitian tentang alat tenun tradisional yang diberi judul"STRATEGI THREE IN ONE DALAM MERANCANG ALAT TENUN TRADISIONAL NTT di RUMAH TENUN KAMPUNG ALOR". Penulis mengharapkan penelitian tersebut dapat memberikan inovasi terbaru pada alat tenun tradisional di masa yang akan datang.

\section{METODE PENELITIAN}

Metode penelitian yang digunakan dalam kajian ini adalah pengamatan/observasi, dan wawancara/interview. Sesuai dengan pokok permasalahan yang dikaji, penelitian ini menggunakan pendekatan kualitatif, yang mempunyai sifat deskriptif. Artinya permasalahan yang dibahas dalam penelitian tidak berkenaan dengan angka-angka tetapi bertujuan untuk menggambarkan atau menguraikan tentang ha-hal yang berhubungan dengan keadaan atau suatu fenomena (Moleong, 1994 : 103).

Alasan digunakannya metode tersebut diantaranya adalah tidak melakukan pengetesan atau pengujian hipotesis, melainkan berusaha menelusuri, memahami, menjelaskan strategi three in one dalam perancangan alat tenun tanpa menghilangkan unsur tradisional. Maka dari itu peneliti menghimpun data dengan menggunakan metode diatas antara lain :

- Pengamatan/Observasi

Observasi atau yang disebut pula dengan pengamatan meliputi kegiatan pemusatan perhatian terhadap suatu obyek dengan menggunakan seluruh alat indra (Arikunto, 1989: 128). Dalam melakukan observasi ini yang menjadi sumber data adalah alat tenun tradisional dalam membuat kain tenun,dimana penulis mengamati secara cermat, bagaimana proses kerja alat tenun dan cara pengerjaan atau produksi selembar kain tenun.

Cara pengambilan data yang dilakukan adalah dengan melihat atau mengamati semua yang terjadi sebelum dan sesudah dilakukan oleh pengrajin dalam mengoperasikan alat tenun dalam pembuatan kain tenun, serta juga melakukan pengamatan terhadap lokasi dan lingkungan tempat industri sarung tenun pada rumah tenun kampung Alor di Kecamatan Oebobo, Kota Kupang. Aspek pengamatan ditujuhkan pada 
kondisi fisik industri, fasilitas, pemilik Rumah Tenun Kampung Alor, dan tenaga kerja (pengrajin).

\section{- Wawancara/Interview}

Wawancara atau interview adalah usaha mengumpulkan informasi dengan mengajukan sejumlah pertanyaan secara lisan, dan untuk menjawab secara lisan.Ciri utama interview adalah kontak langsung dengan sumber informasi.Dalam penelitian ini penulis melakukan wawancara dengan pemilik rumah tenun kampung Alor serta pelaku produksi atau para pengrajin tenun ikat dirumah tenun kampong alor itu sendiri.

Aspek-aspek yang diwawancarakan dengan pemilik rumah tenun kampung alor adalah tentang gambaran umum rumah tenun seperti lokasi dan kondisi geografis, sejarah berdirinya serta perkembangan rumah tenun kampung Alor, alat dan bahan untuk menunjang proses produksi kain tenun, fasilitas yang diberikan kepada para pengrajin dan keterampilan yang dimiliki oleh para pengrajin serta harapan untuk perkembangan tenun ikat terkhususnya pada perkembangan alat tenun tradisional NTT kedepannya.

Sedangkan hal-hal yang diwawancarakan dengan pengrajin di rumah tenun kampong Alor adalah alat dan bahan untuk produksi kain tenun, cara kerja atau cara mengoperasikan alat tenun, fakor pendukung dan kendala apa saja yang dihadapi dalam proses produksi kain tenun, dan apa yang menjadi harapan pada perkembangan kain tenun terkhususnya pada perkembangan alat tenun tradisional NTT kedepannya.

\section{HASIL DAN PEMBAHASAN}

Pengambilan data merupakan suatu langkah yang paling menentukan dari suatu penelitian, karena pengambilan data merupakan hasil dari penelitian.Penngambilan data dapat dilakukan melalui tahap berikut ini.

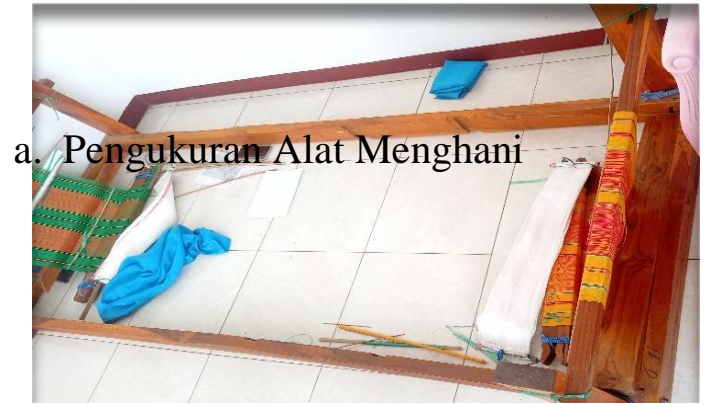

Gambar 4.1 Pengukuran Alat Menghani

Alat Menghani merupakan alat yang digunakan untuk menata benang lungsing dan untuk menentukan ukuran kain yang akan dibuat. Pada proses ini, harus dilakukan pengukuran yang teliti pada tiap

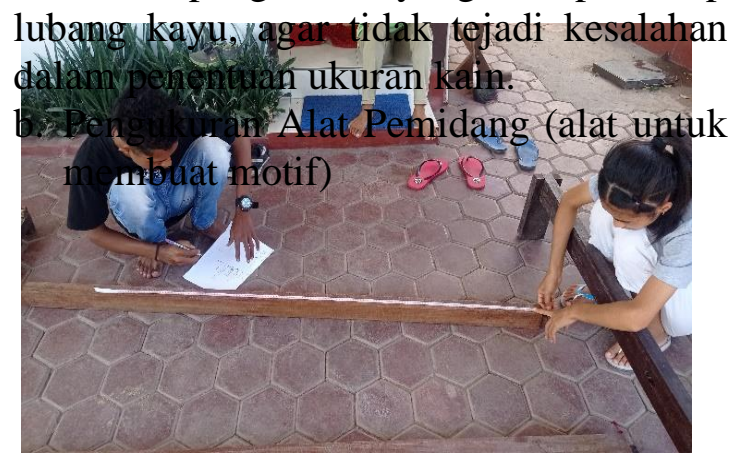

Gambar 4.2 Pengukuran Alat Pemidang

Setelah menghani, benang-benang kemudian dipindahkan ke alat pemidang yang kemudian dilanjutkan pada proses pengerjaan ragam hias atau motif. Pemidang merupakan alat yang digunakan untuk membuat motif.

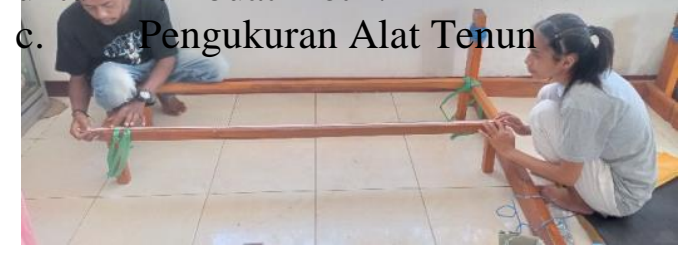


Gambar 4.3 Pengukuran Alat Tenun

Alat tenun ini sendiri juga merupakan alat yang digunakan dalam proses menenun helaian benang menjadi kain-kain. Sehingga untuk pengukurannya sendiri juga harus teliti terlebih pada tinggi tiang penyangga dan tumpuan kaki penenun.

\section{Hasil Pengukuran}

Hasil pengukuran alat menghani, alat pemidang dan alat tenun dapat dilihat ukuran kayu pada setiap bagian alat dan jumlah kayu yang dibutuhkan pada setiap alat tersebut seperti pada tabel 4.1 dibawah ini serta pada lampiran 1,2, dan 3:

Tabel 4.1 Data Hasil Pengukuran

\begin{tabular}{|c|c|c|c|c|c|}
\hline \multirow[t]{2}{*}{ NO } & \multirow{2}{*}{$\begin{array}{l}\text { Bagian- } \\
\text { Bagian Alat }\end{array}$} & \multicolumn{3}{|c|}{ UKURAN (cm) } & \multirow{2}{*}{$\begin{array}{l}\text { Jumlah } \\
\text { Kayu } \\
\text { (batang } \\
\text { ) }\end{array}$} \\
\hline & & $\begin{array}{l}\text { Panjan } \\
\mathrm{g} \quad(\mathbf{P}) \\
\text { per } \\
\text { Kayu }\end{array}$ & $\begin{array}{l}\text { Lebar (L) per } \\
\text { Kayu }\end{array}$ & $\begin{array}{l}\text { Tinggi } \\
\text { (T) per } \\
\text { Kayu }\end{array}$ & \\
\hline 1. & $\begin{array}{l}\text { Palang } \\
\text { Panjang } \\
\text { Atas }\end{array}$ & 220 & 4 & 10 & 2 \\
\hline 2. & $\begin{array}{l}\text { Palang } \\
\text { Lebar Atas }\end{array}$ & 112 & 4 & 4 & 3 \\
\hline 3. & $\begin{array}{l}\text { Palang } \\
\text { Panjang } \\
\text { Bawah }\end{array}$ & 220 & 4 & 10 & 2 \\
\hline 4. & $\begin{array}{l}\text { Palang } \\
\text { Lebar } \\
\text { Bawah }\end{array}$ & 112 & 4 & 10 & 2 \\
\hline 5. & $\begin{array}{l}\text { Palang } \\
\text { Tumpuan } \\
\text { Kaki }\end{array}$ & 87 & 4 & 10 & 2 \\
\hline 6. & $\begin{array}{l}\text { Tiang } \\
\text { Penyangga }\end{array}$ & 10 & 10 & 50 & 4 \\
\hline
\end{tabular}

\section{Pembahasan}

Berdasarkan hasil pengukuran pada tabel 4.1 maka dibuatlah suatu inovasi dengan strategi three in one sehingga menghasilkan ukuran alat tenun tradisional NTT yang berbeda dengan ukuran alat tenun pada umumnya. Ukuran hasil inovasi dengan strategi three in one dapat dilihat pada tabel dibawah ini:

a. Ukuran alat tenun tradisional hasil inovasi dengan strategi three in one

\begin{tabular}{|c|c|c|c|c|c|c|}
\hline \multirow[t]{2}{*}{ No } & \multirow{2}{*}{$\begin{array}{l}\text { Nama } \\
\text { Alat }\end{array}$} & \multirow{2}{*}{$\begin{array}{l}\text { Bagian-Bagian } \\
\text { Alat }\end{array}$} & \multicolumn{3}{|c|}{ UKURAN (cm) } & \multirow{2}{*}{$\begin{array}{l}\text { Jumla } \\
\text { h } \\
\text { Kayu } \\
\text { (batan } \\
\text { g) }\end{array}$} \\
\hline & & & $\begin{array}{l}\text { Panjang } \\
\text { (P) per } \\
\text { Kayu }\end{array}$ & $\begin{array}{l}\text { Lebar } \\
\text { (L) } \\
\text { per } \\
\text { Kayu }\end{array}$ & $\begin{array}{l}\text { Tinggi } \\
\text { (T) } \\
\text { per } \\
\text { Kayu }\end{array}$ & \\
\hline \multirow{3}{*}{1.} & \multirow{3}{*}{$\begin{array}{l}\text { Alat } \\
\text { Mengh } \\
\text { ani }\end{array}$} & Palang Panjang & 200 & 8 & 4 & 2 \\
\hline & & Palang Lebar & 187 & 8 & 2 & 2 \\
\hline & & Tiang Kaki & 4 & 8 & 25 & 4 \\
\hline \multirow{3}{*}{2.} & \multirow{3}{*}{$\begin{array}{l}\text { Alat } \\
\text { Pemida } \\
\text { ng }\end{array}$} & Palang Panjang & 145 & 4 & 4 & 2 \\
\hline & & Palang Lebar & 40 & 4 & 4 & 2 \\
\hline & & Tiang Kaki & 4 & 4 & 21 & 4 \\
\hline \multirow{4}{*}{3.} & \multirow{4}{*}{$\begin{array}{l}\text { Alat } \\
\text { Tenun }\end{array}$} & $\begin{array}{l}\text { Palang Panjang } \\
\end{array}$ & 220 & 4 & 10 & 2 \\
\hline & & $\begin{array}{l}\text { Palang } \\
\text { Tumpuan Kaki }\end{array}$ & 112 & 4 & 10 & 2 \\
\hline & & $\begin{array}{l}\text { Penyangga } \\
\text { Kain }\end{array}$ & 110 & 4 & 4 & 2 \\
\hline & & $\begin{array}{l}\text { Tiang } \\
\text { Penyangga }\end{array}$ & 10 & 4 & 50 & 4 \\
\hline
\end{tabular}

Tabel 4.2 Data Pengukuran Hasil Inovasi

b. Hasil Alat Tenun setelah inovasi

Berdasarkan ukuran hasil inovasi alat tenun dengan menggunakan strategithree in one pada tabel 4.2, maka dibuatlah suatu alat tenun tradisional NTT seperti pada gambar 4.4. Alat tenun tradisional tersebut dapat menjawab permasalahan yang dialami seperti masalah pada kesehatan pengrajin, masalah waktu serta tempat yang tidak efisien dalam proses

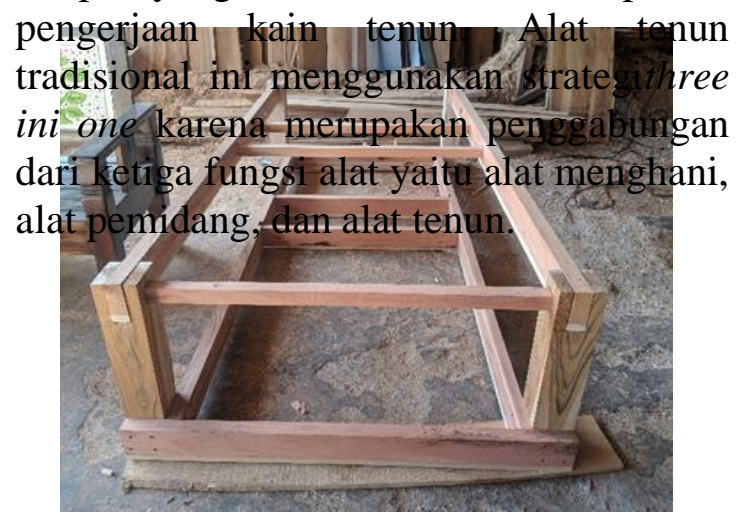




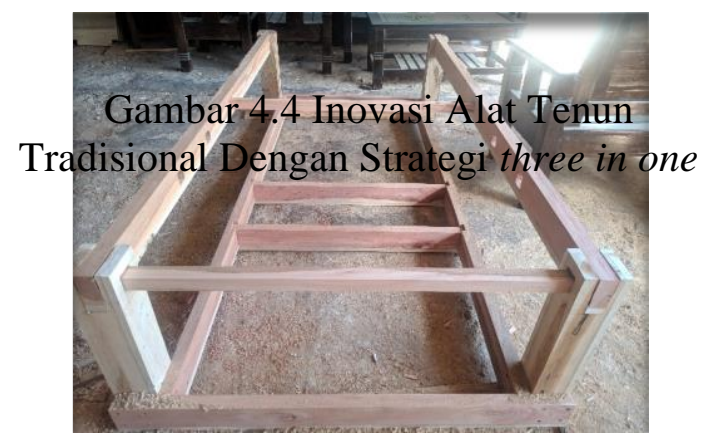

Gambar 4.5 Inovasi Alat Menghani

Cara penggunaan alat menghani hasil inovasi adalah dengan cara bongkar pasang (knock down) melalui lubang pat kan
Gambar 4.5
Dengan menyesuaikan ukuran kain pada
alat atau pada usuk bagian atas.

Gambar 4.6 Inovasi Alat Pemidang Sama seperti alat menghani, penggunaan alat pemidang hasil inovasi juga dengan cara bongkar pasang pada alat atau usuk kay a din yang akan dibuat pada ukuran
ukuran kain
lubang pada kayu atau seperti pada
Gambar 4.6
Gambar 4.7 Inovasi Alat Tenun

Penggunaan alat tenun hasil inovasi adalah seperti pada alat tenun umumnya, dengan melepas kayu palang dan usuk bagian atas kecuali pada usuk depan dan belakang bagian atas yang berfungsi sebagai penyangga kain tenun pada proses menenun seperti pada gambar 4.7

\section{KESIMPULAN}

Berdasarkan uraian-uraian dan analisis data yang telah dijelaskan pada bab-bab sebelumnya, maka kesimpulan dari penelitian yang berjudul "INOVASI ALAT TENUN TRADISIONAL NTT DENGAN STRATEGITHREE IN ONE" adalah:

1. Alat tenun secara umum merupakan alat atau mesin untuk menenun benang menjadi tekstil (kain). Alat tenun tradisional metode three in one sudah di implementasikan di Rumah Tenun Kampung Alor. Alat tenun hasil modifikasi mempermudah pengrajin dalam menenun karena tidak harus berpindah - pindah dari satu alat ke alat yang lain, yang berarti terjadinya penghematan waktu kerja.

2. Faktor-faktor yang menjadi penghambat dalam proses menenun adalah:

Masalah pada kondisi kesehatan pengrajin seperti; sikap duduk terlalu lama dapat menyebabkan otot perut melembek dan tulang belakang melengkung sehingga cepat lelah dan juga sakit pada lutut, pinggang dan pinggul.

Masalah waktu serta tempat yang tidak efisien. Dalam hal ini, pada proses pengerjaan sebuah kain tenun biasanya dibutuhkan tiga alat berbeda yang mana dalam proses pengerjaannya ketiga alat tersebut harus digunakan secara bergantian sehingga memakan waktu yang lama. Ketiga alat tersebut juga membutuhkan tempat yang luas 
dalam proses pengerjaan kain tenun.

\section{REFERENSI}

[1] J. van der Geer, J.A.J. Hanraads, R.A. Lupton, The art of writing a scientific article, J. Sci. Commun. 163 (2000) 51-59.

[2] W. Strunk Jr., E.B. White, The Elements of Style, third ed., Macmillan, New York, 1979.

[3] G.R. Mettam, L.B. Adams, How to prepare an electronic version of your article, in: B.S. Jones, R.Z. Smith (Eds.), Introduction to the Electronic Age, E-Publishing Inc., New York, 1999, pp. 281-304.

[4] R.J. Ong, J.T. Dawley and P.G. Clem: submitted to Journal of Materials Research (2003)

[5] P.G. Clem, M. Rodriguez, J.A. Voigt and C.S. Ashley, U.S. Patent 6,231,666. (2001)

[6] Information on

http://www.weld.labs.gov.cn 